\title{
QRishing: A User Perspective
}

\author{
Ari Kusyanti \\ Department of Information Technology \\ Universitas Brawijaya \\ Malang, Indonesia
}

\author{
Ali Arifin \\ Department of Information System \\ Universitas Brawijaya \\ Malang, Indonesia
}

\begin{abstract}
QR Code offers more benefits and features than its predecessor, Barcode, which make it more popular. However, there is no doubt that behind the features and conveniences offered by QR Code, it turns that the QR Code can be utilized to perform QRishing. This study proposes a model based on Technology Acceptance Model (TAM) combined with Perceived Security, Trust, Perceived Behavioral Control, Self-Efficacy and Perceived Risk based on previous research. Data obtained from 300 respondents are then analyzed with Structural Equation Modeling (SEM). The results show that Attitude, Perceive Security and Perceived Risk affect the individual to scan QR Code.
\end{abstract}

Keywords-QR code; perceived risk; perceived privacy; trust; Structural Equation Modeling (SEM)

\section{INTRODUCTION}

QR Code is getting more attention in some countries based on the results on the investigation of ScanLife [1] in 2015, which showed that the United States, Spain, France, Brazil and Mexico are five most active countries that scan the QR Code to access product information, entertainment video, mobile applications, etc. Google Trends [2] also conducted a survey of QR Code trend in November 2015-October 2016, with Hong Kong, Taiwan, Singapore, Germany and Austria as the five most active countries scanning the QR Code.

In Indonesia, the use of QR Code is started by Indonesian Ministry of Public Transportation in order to improve public services in traffic and online sea transportation by the Sistem Manajemen Lalu Lintas Angkutan Laut (SIMLALA) application [3]. In addition, Indonesian General Department of Taxation also uses QR Code for their e-invoice payment system [4]. In addition, Lembaga Pangan Pengkajian Obatobatan dan kosmetika Majelis Ulama Indonesia (LPPOMMUI) has built QR Code Scanner-based applications to enable customers to check the halal certification of a product through the device such as mobile phones [5]. Some of the above examples indicate that the use of QR Code in Indonesia has been getting more popularity.

Research conducted by [6] examines how users interact with QR Code that is placed in an urban space called PlaceTagz. PlaceTagz is located in various locations located in Melbourne such as cafeterias, libraries and public toilets. When someone scans PlaceTag, the person is taken to a dialog box where he can read comments from previous visitors and also that person can leave his own comments. The results of this study indicate that curiosity is the primary motive of users to scan non-contextual QR codes. With curiosity being the primary motivation of the user to interact with unknown sources, the user tends to ignore security threats related to the source of the QR Code whether verified correctly or not. It has been found several cases related to QR Code, such as that one of Heinz customer (Heinz known as a food processing company in Germany) reported that the QR Code has been scanned in order to follow the Heinz company promotion to order a bottle of tomato sauce but in fact it is instructed her to direct to a porn company site called FunDorado [7]. Other case had occurred in Russia, that the perpetrator of a crime use QR Code technology to attract users so that they download Android apps that contain malware. Applications downloaded by the target named Jim then will send a text message to victims who can steal up to 5 USD victim's air time [8].

Given the considerable risks posed by the QR Code, it is worth a study to further examining this issue. Kieseberget et al. [9] has been conducting research with respect to the QR Code and how QR Code can be used to attack the target by manipulating the QR Code to make the target interested to scan it. After scanning, the target will get caught in the phishing attack that had been planned by the attackers, known as QRishing. This is due to most of users are less paying attention to security and trusting the QRCode which they scan. In addition, research that examines aspects of human and computer interactions especially in the field of QR Code security has been done by [6] and [10].

In a study conducted by [10] found that $\mathrm{QR}$ code-initiated phishing attacks by conducting two experiments in the city of Pittsburgh, surveillance and a QRishing experiment. Within their surveillance experiment, they observe how users interact with QR Code and whether the user is scanning QR Code or not. Furthermore they also observe the proportion of users who scan the code but refuse to visit the encoded URL by visually monitoring the interaction of the user. To perform the experiment, they put up QR Code posters and cameras used to record the interaction of the user. In this experiment, they divided the QR Code on three types of posters and leaflets to find out assess the susceptibility of such a phishing attack. In their deployed QR codes, a link to a survey was encoded. The experiment contains a series of questions used to identify factors and behaviors of people who scan QR Code. Similar to research conducted by [10], research [6] found that curiosity is the main motivation for smartphone users to scan the code. Their findings highlight the need for further research on adequate tools to support the user in detecting potential threats as they are mostly scanning unverified codes because of their curiosity. Their results also found that most of the users who scan the QR Code do not provide the proper tools to be able to 
automatically detect attacks and minimize the impact of user's privacy and security.

However apart from its sophistication and ease of use, QR Code also causing damage. However, this study did not model the behavior of QR Code users that may explain why they want to scan a QR Code. Specifically, our study proposes a similar study on the QR Code by modeling the QR Code user behavior which is a modified research models of Cheng et al. [11]; Shin [12]; Ajjan and Hartshorne [13]; and Martins et al. [14].

The outline of this research is in Section 1 explains the background of the issues raised, while Section 2 describes the literature review which contains an explanation of the QR Code and the variables used in this study. Section 3 explained research model to be used along with the formulation of the hypothesis. Afterwards, Section 4 describes the data analysis and presented in the form of data, and in Section 5 is the discussion exposure from the results of data analysis that has been done. Finally Section 6 is the exposure of the conclusions from the results of data analysis that has been obtained.

\section{LITERATURE REVIEW}

\section{A. QR Code}

Quick Response (QR) Code is a matrix of two-dimensional black and white pixels that can be used to store or encode data or information, which information or data can be obtained simply by scanning the QR Code [15]. The information encoded in the vertical and horizontal directions, thus the data can be stored several hundred times more than the Barcode. QR Code can be read by a QR reader application. Data can be accessed only by capturing the QR Code images using the smart phone's camera, then the QR reader application will process the image to be interpreted and displayed to the smart phone screen [9]. QR Code is more popular because of higher information density and increasing the reading compared with Barcode [15].

For our study, we perform a modification of QRishing, we placed posters in our university and nearby as in Fig. 1 from 23 November - 30 of December 2016. The poster is actually a fake promotional poster which offers respondents with a free USB Stick as a reward if they scan the QRCode. This poster contains the URL address (http://tinyurl.com/KuisionerQRCode) which is a page for fill in the online questionnaire. The poster is actually a fake promotional poster which offers respondents with a free USB Stick as a reward if they scan the QRCode.

\section{B. Technology Acceptance Model with the Addition of Perceived Web Security Construct}

TAM is a comprehensive research model used to predict the acceptance factor for someone to use the services of a particular technology or information systems. Research conducted by [11] discussed factors affecting clients to use the Internet Banking (IB). The theoretical model in this study based on the Technology Acceptance Model (TAM) with the addition of perceived web security construct to predict customer behavior intention to adopt IB. Retrieving data using questionnaires to 203 customers in Hong Kong were selected randomly. Then the data were analyzed using the Structured Equation Modeling (SEM) to evaluate the strength of the relationship between the hypothetical construction which includes Perceived Ease of Use and Perceived Web Security, Perceived Usefulness, Attitude and Intention to Use. The results showed that Attitude, Perceived Web Security and Perceived Usefulness effect on person's intention to use IB.

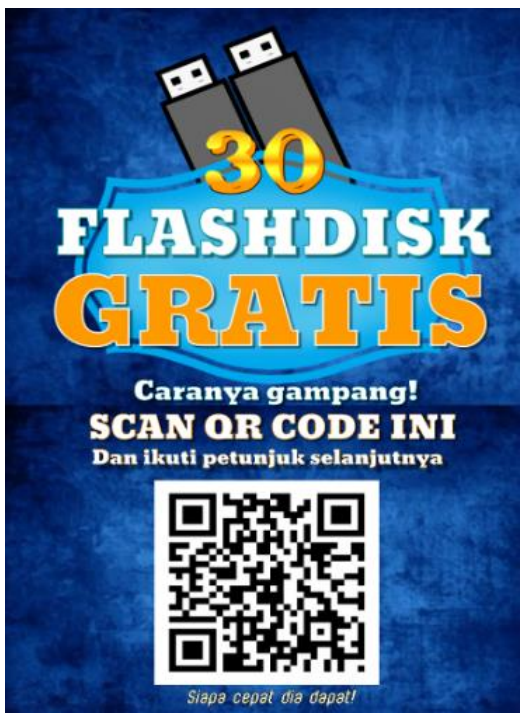

Fig. 1. Poster containing QR code.

\section{Trust, Security and Privacy}

Research conducted by [12] discussed the effect of trust, security, and privacy of the individual to use social networking sites. Retrieving data from questionnaires of 370 students of Sungkyunkwan University in South Korea, the data were analyzed using the Structured Equation Modeling (SEM) to evaluate the strength of the relationship between the hypothetical construction which includes Perceived Security, Perceived Privacy, Trust, Attitude and Intention. The findings indicate that the Trust affect Attitude, then Security affects the Trust which was adopted in this study.

\section{Decomposed Theory of Planned Behavior (DTPB)}

Research conducted by [13] discussed the factors that influence the decision of the Faculty at the University of North Carolina United States to adopt Web technologies 2.0 in the methods of learning in the classroom. As for the research model used is decomposed Theory of Planned Behavior (DTPB). The results showed that the Subjective Norm does not affect Behavior Intention, then only Self Efficacy affecting Perceived Behavioral Intention which was adopted in this study.

\section{E. Unified Theory of Acceptance and Use of Technology (UTAUT) and Perceived Risk}

Research conducted by [14] discussed with respect to understanding the determinants of major adoption of Internet Banking (IB) for banks and customers. The results of the study support some of UTAUT relationship, such as Performance Expectancy, Effort Expectancy, Social Influence and also the role of risk (Perceived Risk) strongly influence Intention which was adopted in this study. 


\section{MODEL STRUCTURE AND HyPOTHESIS}

This study uses model from [11] with TAM and Perceived Web Security constructs that has been modified to determine the factors that affect a person using QR Code. The model is also combined with the Trust construct from [12], Subjective Norm construct and Perceived Behavioral Control construct from [4], and Perceived Risk construct from [14].

\section{A. Constructs Definition}

In this study, there were 13 constructs variable included four constructs of variables which is a second order (performance risk, time risk, social risk, overall risk), and 40 indicators variable. The definition of each construct can be seen in Table 1.

\section{B. Hypothesis for the Construct}

Adapted from [11], their study using the Technology Acceptance Model (TAM) from [11], with some additional constructs, there are behavioral intention to use, attitude, perceived ease of use and perceived usefulness, then combined with the perceived web security based on research from [11], to determine the factors that affect a person using the IB service. Their study said that the findings are consistent with the findings of [11], where the perceived usefulness (PU) has a strong influence on customer intention to use IB services. Perceived ease of use (PEOU) has influence on perceived usefulness (PU), or it can be said that PEOU have an indirect impact on the intention. According to Davis et al. (1989) cited in [11], PEOU has influence on intention. Referring to [11] that the feeling of safety (perceived web security) is the main factors that influence a person to conduct transactions online, and this finding is consistent with [11]. The final result of [11] shows all the hypotheses are accepted, which are adopted in this study to analyze the factors that affect a person using QR Code. So, from all these statements, we propose the following hypotheses:

H1a: "Perceived Ease of Use (PEOU)" has a positive effect on "Perceived Usefulness (PU)".

H1b: "Perceived Ease of Use (PEOU)" has a positive effect on "Intention to Scan (ITS)".

H2a: "Perceived Usefulness (PU)" has a positive effect on "Attitude (ATT)".

H2b: "Perceived Usefulness (PU)" has a positive effect on "Intention to Scan (ITS)".

H3: "Attitude (ATT)" has a positive effect on "Intention to Scan (ITS)".

H5b: "Perceived Security (PS)" has a positive effect on "Intention to Scan (ITS)".
TABLE I. CONSTRUCTS DEFINITION

\begin{tabular}{|c|c|c|}
\hline Construct & Definition & Ref \\
\hline $\begin{array}{l}\text { Perceived } \\
\text { Usefulness (PU) }\end{array}$ & $\begin{array}{l}\text { The extent to which a } \\
\text { person believes that using } \\
\text { a particular system would } \\
\text { enhance his job } \\
\text { performance }\end{array}$ & {$[11]$} \\
\hline $\begin{array}{l}\text { Perceived Ease of } \\
\text { Use (PEOU) }\end{array}$ & $\begin{array}{l}\text { The extent to which a } \\
\text { person believes that using } \\
\text { a particular system would } \\
\text { be free from excessive } \\
\text { effort }\end{array}$ & {$[11]$} \\
\hline $\begin{array}{l}\text { Perceived } \\
\text { Security (PS) }\end{array}$ & $\begin{array}{l}\text { The extent to which a } \\
\text { person believes that the } \\
\text { using a particular system } \\
\text { is safe }\end{array}$ & {$[11]$} \\
\hline Attitude (ATT) & $\begin{array}{l}\text { Referring to the positive or } \\
\text { negative feelings that } \\
\text { affect individual people } \\
\text { perform certain behaviors }\end{array}$ & [11] \\
\hline $\begin{array}{l}\text { Intention to Scan } \\
\text { (ITS) }\end{array}$ & $\begin{array}{l}\text { Referring to the person's } \\
\text { intent to use (scan QR } \\
\text { Code) }\end{array}$ & {$[11]$} \\
\hline Trust (T) & $\begin{array}{l}\text { The trust in the other party } \\
\text { that they will behave } \\
\text { according to expectations }\end{array}$ & {$[12]$} \\
\hline $\begin{array}{l}\text { Perceived } \\
\text { Behavioral } \\
\text { Control (PBC) }\end{array}$ & $\begin{array}{l}\text { Individual perceptions } \\
\text { about how easy or difficult } \\
\text { it is to behave as the effect } \\
\text { of perceived behavioral } \\
\text { control }\end{array}$ & {$[13]$} \\
\hline $\begin{array}{l}\text { Self-Efficacy } \\
\text { (SE) }\end{array}$ & $\begin{array}{l}\text { Self-efficacy is defined as } \\
\text { the ability of individuals } \\
\text { perceived to behave in } \\
\text { certain ways }\end{array}$ & {$[13]$} \\
\hline \multicolumn{3}{|c|}{ Perceived Risk (PCR) } \\
\hline $\begin{array}{l}\text { Performance } \\
\text { Risk (PFR) }\end{array}$ & $\begin{array}{l}\text { Possible outcomes are not } \\
\text { suitable as desired, and } \\
\text { therefore failed to provide } \\
\text { the desired benefits }\end{array}$ & {$[14]$} \\
\hline Time Risk (TR) & $\begin{array}{l}\text { Time risk occurs when } \\
\text { users lose time due to } \\
\text { adopt a particular } \\
\text { technology or service }\end{array}$ & {$[14]$} \\
\hline Social Risk (SR) & $\begin{array}{l}\text { Social risk reflects the } \\
\text { potential loss of status in } \\
\text { social groups, as a result } \\
\text { of adopting a particular } \\
\text { technology or service }\end{array}$ & {$[14]$} \\
\hline $\begin{array}{l}\text { Overall Risk } \\
\text { (ORI) }\end{array}$ & $\begin{array}{l}\text { Overall risk as a result of a } \\
\text { combination of risks }\end{array}$ & {$[14]$} \\
\hline
\end{tabular}


Adapted from [12] that perceived security is defined as the degree of how a person's trust in the security of the QR Code [12], found that the perception of security affect a person's trust and intention. This is consistent with the [12] finding that the security determines the level of trust. Then Papadopoulou [12] found that there is a positive influence on the attitude of trust and intentions. So, from all these statements, we propose the following hypotheses:

H5a: "Perceived Security (PS)" has a positive effect on "Trust (T)".

H4a: "Trust (T)" has a positive effect on "Attitude (ATT)".

H4b: "Trust (T)" has a positive effect on "Intention to Scan (ITS)"'.

Based on [13] defines that perceived behavioral control is an individual's perception of how easy or difficult it is to behave as the effect of perceived behavioral control. In [13] found that attitudes and perceived behavioral control have a strong positive influence on the behavioral intention, but subjective norm have no influence on behavioral intention, this is consistent with [13]. So, from all these statements, we propose the following hypotheses:

H6: "Perceived Behavioral Control (PBC)" has a positive effect on "Intention to Scan (ITS)".

H7: "Self Efficacy (SE)" has a positive effect on "Perceived Behavioral Control (PBC)".

Adapted from [14] defines that performance risk, financial risk, time risk, psychological risk, social risk, privacy risk and overall risk is an indicator of second order of perceived risk affecting intention. This is consistent with the finding of [14] that the perceived risk is an important factor that affects a person's intention in using IB which was adopted and adapted by the authors to analyze the factors that affect a person using QR Code. So, from all these statements, we propose the following hypotheses:

H8: "Perceived Risk (PCR)" has a positive effect on "Intention to Scan (ITS)".

Based on hypotheses that have been formulated above, the research model can be seen in Fig. 2.

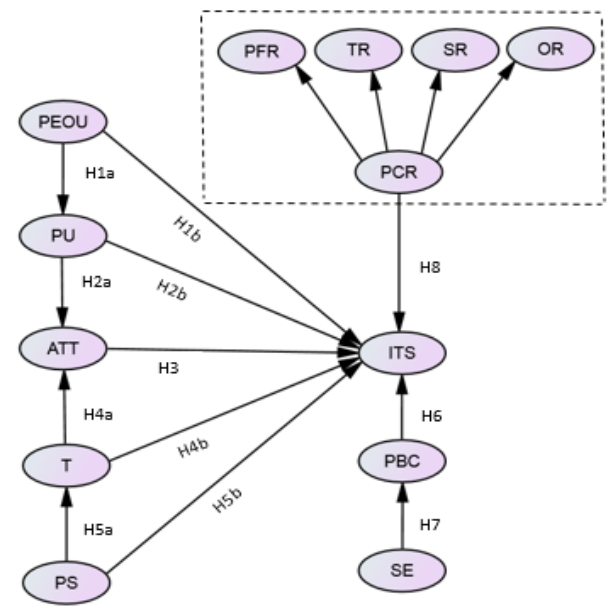

Fig. 2. Reasearch model.

\section{DATA ANALYSIS}

Respondents in this study is not limited by certain criteria, including the age or gender, everyone can participate as a respondent after scanning the $\mathrm{QR}$ Code found on the posters have been distributed by the author, then the respondent will be redirected to the page of filling the questionnaire online which in this study using a Google Form. 300 respondents were obtained for analysis in this study. The sample data were analyzed using SEM (Structural Equation Modeling). The ideal sample size data on SEM method preferably ranges from 200 to 400 data for the model studies with 10-15 observed variables. The author took the middle value of 300 data because if the sample data are below 100 or above 300 , it can provide unfavorable analytical results [16].

From the result of filling the online questionnaire by respondents, there are no questionnaires were incomplete and all have passed the test of missing data. For the characteristics of the respondent can be seen in Table 2.

TABLE II. RESPONDENTS CHARACTERISTIC

\begin{tabular}{|c|c|c|c|c|c|}
\hline Age & Total & $\%$ & Gender & Total & $\%$ \\
\hline \multirow{2}{*}{$<20$} & \multirow{2}{*}{64} & \multirow{2}{*}{21,33} & Male & 40 & 62,5 \\
\hline & & & Female & 24 & 37,5 \\
\hline \multirow{2}{*}{$20-29$} & \multirow{2}{*}{236} & \multirow{2}{*}{78,67} & Male & 119 & 50,42 \\
\hline & & & Female & 117 & 49,58 \\
\hline
\end{tabular}

A. Outlier Test

Outlier test is performed by calculating Mahalanobis distance value. In this study the Mahalanobis distance value is 63.69073975. There are 40 data that has value above Mahalanobis distance so that this data can be called outliers and should be eliminated.

\section{B. Missing Data and Outlier}

Based on Little's MCAR, there is no missing data in this study. Mahalanobis distance is used to determine outlier data. Data which has Mahalanobis distance of more than 34,805 is considered the outlier and need to be withdrawn. From 300 questionnaires collected, there are 12 outlier data, so the eligible data to be analyzed are 288 data.

\section{Reliability and Validity Test}

Reliability can be defined as trust, reliability or consistency [17]. A measuring instrument can be said to be reliable if it is have a high level of consistency (high reliability). Reliability test can be measured using Cronbach's alpha values [18], grouping reliability criteria based on the value of Cronbach's alpha, which is excellent if $(\alpha \geqslant 0,9)$, good $(\alpha \geqslant 0,8)$, acceptable $(\alpha \geqslant 0,7)$, questionable $(\alpha \geqslant 0,6)$, poor $(\alpha \geqslant 0,5)$ and unacceptable $(\alpha<0.5)$. Referring to Table 3, the authors using Cronbach's alpha values above 0.7 to determine the level of consistency of respondents, in other words, the data can be said to be reliable if it has a value of Cronbach's alpha of more than 0.7 .

To test the validity can be tested by average variance extracted (AVE) for each construct [19]. AVE value can be seen in Table 4 for each variable construct in this study. An indicator is said to be valid and worthy to be tested further if the AVE value is greater than 0.5 [19]. 
From Table 4 it is shown that the AVE value of each construct is more than of 0.5 [19], so it can be said good because of all the variables of indicators has met the AVE criteria.

TABLE III. CRonbach Alpha Value

\begin{tabular}{|l|l|l|}
\hline Construct & $\begin{array}{l}\text { Cronbach's } \\
\text { alpha }\end{array}$ & Explanation \\
\hline $\begin{array}{l}\text { Perceived Usefulness } \\
\text { (PU) }\end{array}$ & 0,922 & Excellent \\
\hline $\begin{array}{l}\text { Perceived Ease of } \\
\text { Use (PEOU) }\end{array}$ & 0,899 & Good \\
\hline Trust (T) & 0,890 & Good \\
\hline $\begin{array}{l}\text { Perceived Security } \\
\text { (PS) }\end{array}$ & 0,944 & Excellent \\
\hline Attitude (ATT) & 0,902 & Excellent \\
\hline $\begin{array}{l}\text { Intention to Scan } \\
\text { (ITS) }\end{array}$ & 0,937 & Excellent \\
\hline $\begin{array}{l}\text { Performance Risk } \\
\text { (PFR) }\end{array}$ & 0,871 & Excellent \\
\hline Time Risk (TR) & 0,922 & Excellent \\
\hline Social Risk (SR) & 0,937 & Excellent \\
\hline Overall Risk (ORI) & 0,919 & Excellent \\
\hline $\begin{array}{l}\text { Perceived Behavioral } \\
\text { Control (PBC) }\end{array}$ & 0,789 & 0,901 \\
\hline Self-Efficacy (SE) & & \\
\hline
\end{tabular}

TABLE IV. CONVERgENT VALIDITY EXTRACTED (AVE)

\begin{tabular}{|l|l|}
\hline Construct & AVE \\
\hline PEOU & 2.341 \\
\hline PU & 2.5351 \\
\hline ATT & 2.8826 \\
\hline T & 2.3841 \\
\hline ITS & 1.5338 \\
\hline PS & 1.829 \\
\hline SE & 1.6926 \\
\hline PBC & 1.6846 \\
\hline PFR & 1.9139 \\
\hline TR & 1.2694 \\
\hline SR & 1.2694 \\
\hline ORI & 2.1758 \\
\hline
\end{tabular}

\section{KMO and Bartlett's Test}

Kaiser-Meyer-Olkin (KMO) and Bartlett's test was used to determine whether the sample data used in the study is sufficient to analyze certain factors. According to [20], it breaks down in detail the criteria of KMO and Bartlett's test that can be seen in Table 5. From the calculation results KMO is 0.908 , so it can be said to have a very good criteria (superb). Then for the value of Bartlett's test can be seen to have a value of 0,000 so it can be said to be very significant.

TABLE V. KMO AND BARTLETT'S TEST

\begin{tabular}{|l|l|l|l|}
\hline \multicolumn{1}{|c|}{ Index } & Value & Criteria & \multirow{2}{*}{ Ref } \\
\hline \multirow{4}{*}{$\begin{array}{l}\text { Kaiser-Meyer- } \\
\text { Olkin }\end{array}$} & \multirow{2}{*}{0,908} & $<0,5$ unacceptable & \\
& & $0,5-0,7$ mediocre & \\
& & $0,7-0,8$ good & \\
\cline { 3 - 3 } & & $0,8-0,9$ great & \\
\cline { 3 - 3 } & & $>0,9$ superb & \\
\hline $\begin{array}{l}\text { Bartlett's } \\
\text { test }\end{array}$ & 0,000 & $\begin{array}{l}<0,001 \text { highly } \\
\text { significant }\end{array}$ & \\
\hline
\end{tabular}

\section{E. Levene Test}

Levene test is used to determine whether the research data obtained was homogeneous or not. Data are considered homogeneous if the value (Sig.> 0.05), but if the value (Sig. $<0.05)$, then the data is considered not homogeneous [21]. The test results showed that all existing indicator variable has a value of Sig. $>0.05$, so the data is said to be good because it has met the criteria of homegenity.

\section{F. Normality Test}

Normality test is used to determine the normal distribution of the cumulative sample. Normality test can be calculated with the Kolmogorov-smirnov. Samples can be said to be normally distributed because the Sig. 0.2 (meet the criteria Sig.> 0.05) [22].

\section{G. Model Fit}

SEM is performed with two steps, Confirmatory Factor Analysis (CFA) to analyze measurement model and Path Analysis to analyze structural model. CFA test results judged on the criteria of goodness of fit (GOF) for overall fit testing. Overall fit model used for testing the suitability of the model with the research data used. For criteria Goodness of Fit (GOF) can be seen in Table 6 .

\section{H. Model Fit Test Result}

The result of the measurement of goodness of fit is presented in Table 7. Based on these results it can be said that the model used fits the data of respondents. Then for the measurement estimation results of relationship each variable 
constructs and indicators can be seen in Table 7, which is the result of structural test model fit through path analysis. Relations between constructs and indicators according to [23] can be seen by looking at the $\mathrm{p}$-value and critical ratio ( $\mathrm{t}$ value). Referring to the results of the constructs estimation relationship with its indicator refers to Table 8 , can be said that there is a significant relationship between the constructs and indicators. So, constructs variable really suitable for measuring variables existing indicators.

TABLE VI. GOODNESS OF FIT INDICES (GOFI) VALUES

\begin{tabular}{|c|c|c|c|}
\hline Model fit & Item & Criteria & Ref \\
\hline \multirow{6}{*}{$\begin{array}{l}\text { Measurement } \\
\text { model fit }\end{array}$} & Chi-square $\left(\chi^{2}\right)$ & $\mathrm{X}^{2}, \mathrm{df}, \mathrm{p} \geq 0,05$ & [24] \\
\hline & $\begin{array}{l}\text { Goodness of Fit } \\
\text { Index (GFI) }\end{array}$ & $>0,80$ & [25] \\
\hline & $\begin{array}{l}\text { Root Mean } \\
\text { Square Error of } \\
\text { Approximation } \\
\text { (RMSEA) }\end{array}$ & $<0,07$ & [24] \\
\hline & $\begin{array}{l}\text { Root Mean } \\
\text { Square Residual } \\
\text { (RMR) }\end{array}$ & $\leq 0,08$ & [24] \\
\hline & $\begin{array}{l}\text { Normed-fit index } \\
\text { (NFI) }\end{array}$ & $\geq 0,80$ & [24] \\
\hline & $\begin{array}{l}\text { Comparative fit } \\
\text { index (CFI) }\end{array}$ & $\geq 0,80$ & [24] \\
\hline \multirow{3}{*}{$\begin{array}{l}\text { Structural } \\
\text { model fit }\end{array}$} & Factor loading & $\begin{array}{l}>0,5 \text { acceptance } \\
>0,7 \text { good }\end{array}$ & [23] \\
\hline & $\begin{array}{l}\text { Critical ratio (t- } \\
\text { value) }\end{array}$ & $>1,96$ & [23] \\
\hline & $P$ value & $\begin{array}{l}* p<0,05 \\
* * p<0,01 \\
* * * p<0,001\end{array}$ & [26] \\
\hline
\end{tabular}

TABLE VII. Model Fit Test ResUlt

\begin{tabular}{|l|l|l|l|}
\hline Index & Criteria & Value & Explanation \\
\hline Chi-Square & $\mathrm{X}^{2}, \mathrm{df}, \mathrm{p}>0,05$ & 1164,07 & Fit \\
\hline GFI & $>0,80$ & 0,82 & Fit \\
\hline RMSEA & $<0,07$ & 0,05 & Fit \\
\hline RMR & $\leq 0,08$ & 0,05 & Fit \\
\hline NFI & $\geq 0,80$ & 0,88 & Fit \\
\hline CFI & $>0,90$ & 0,94 & Fit \\
\hline
\end{tabular}

\section{Hyphothesis Testing}

Referring to Table 8 that the proposed hypothesis can be said to be accepted if the Critical ratio (t-value) $>1.96$ and pvalue $\leqslant 0.05$. Table 8 presents the results of hypothesis testing, it appears that there are 8 hypothesis is accepted and the two hypothesis are rejected.

\section{RESEARCH RESULT}

\section{A. Discussion on Hypothesis 1}

Based on the hypothesis testing results in Table 8, there are 8 hypotheses that are accepted and the 4 hypothesis are rejected in this study are as follows:

1) Hla: "Perceived Ease of Use (PEOU)" has a positive effect on "Perceived Usefulness (PU)".

$\mathrm{H} 1 \mathrm{a}$ is accepted, which means that perceived ease of use of QR Code is influence the perception that it is true by scanning the QR Code can help respondents to accomplish their activity/job. In this case the initial perceptions of respondents think that by scanning a QR Code can improve performance on their activity/job. These results are consistent with [11] and [26] cited in [11].

TABLE VIII. HYPOTHESIS RESUlT TESTING

\begin{tabular}{|l|l|l|l|}
\hline Relationship & $\begin{array}{l}\text { Critical ratio (t- } \\
\text { value) }\end{array}$ & p-value & Explanation \\
\hline PU <--- PEOU & 13.647 & $* * *$ & Accepted \\
\hline ITS <--- PEOU & -.567 & .571 & Rejected \\
\hline ATT <--- PU & 9.722 & $* * *$ & Accepted \\
\hline ITS <--- PU & 0.659 & 0.51 & Rejected \\
\hline ITS <--- ATT & 8.77 & $* * *$ & Accepted \\
\hline T <--- PS & 10.504 & $* * *$ & Accepted \\
\hline ITS <--- PS & 3.613 & $* * *$ & Accepted \\
\hline ATT <--- T & 6.424 & $* * *$ & Accepted \\
\hline ITS <--- T & -.463 & .643 & Rejected \\
\hline ITS <--- PBC & -1.019 & 0.308 & Rejected \\
\hline PBC <--- SE & 11.563 & $* * *$ & Accepted \\
\hline ITS <--- PCR & 3.981 & $* * *$ & Accepted \\
\hline
\end{tabular}

2) H1b: "Perceived Ease of Use (PEOU)" has a positive effect on "Intention to Scan (ITS)".

$\mathrm{H} 1 \mathrm{~b}$ is rejected, which means that the ease of use of QR Code have no direct effect on respondents' intention to scan the QR Code. PEOU is going to affect the intention only if the existence of perceived usefulness (PU) or if it is useful. So it can be said that PEOU have an indirect impact on intention. These results are consistent with [11].

3) H2a: "Perceived Usefulness (PU)" has a positive effect on "Attitude (ATT)".

$\mathrm{H} 2 \mathrm{a}$ is accepted, which means that respondents find it is worthwhile to scan the QR Code because basically they already have positive feelings toward the QR Code that is scanned by them. These results are consistent with [26] and cited in [11].

4) H2b: "Perceived Usefulness (PU)" has a positive effect on "Intention to Scan (ITS)".

$\mathrm{H} 2 \mathrm{~b}$ is rejected, which means respondents are not going to immediately scan the QR Code even though they know that scanning the QR Code will not be difficult, before they think 
that the decision to scan is completely positive and profitable. These findings are in contrast to [11].

5) H3: "Attitude (ATT)" has a positive effect on "Intention to Scan (ITS)".

H3 is accepted, which means that respondents' attitudes or perspectives influence them to scan the QR Code. Respondents have positive feelings which will encourage them to scan the QR Code were met. These results are consistent with of [11] and [26] cited in [11].

6) H4a: “Trust (T)" has a positive effect on "Attitude $(A T T)^{\prime \prime}$.

$\mathrm{H} 4 \mathrm{a}$ is accepted, which means that respondents' level of trust will affect their attitude or perspective on QR Code scanned by them. If they trust, it would be encouraged them to think positively that scan the QR Code there is nothing wrong and it is a good idea. These findings are consistent with [12], they found that there is a positive influence of trust on the attitude and intentions. It is also consistent with the [12].

7) H4b: "Trust (T)" has a positive effect on "Intention to Scan (ITS)",

$\mathrm{H} 4 \mathrm{~b}$ is rejected, which means that a respondents' level of confidence (trust) has no effect directly on individual intention to scan the QR Code. The trust will affect the intention only if the existence of the attitude, so it can be said that the trust has an indirect impact on intention. The result is different from [12] which mention that there is a positive influence between trust on attitude and intention.

8) H5a: "Perceived Security (PS)" has a positive effect on "Trust $(T)$ ".

H5a is accepted, which means respondents' will trust the QR Code that is scanned by them when they believe that the QR Code is completely safe and harmless. These findings are consistent with [12], their research found that security perceptions (perceptions of security) affect a person's trust. It is also consistent with the [12].

9) H5b: "Perceived Security (PS)" has a positive effect on "Intention to Scan (ITS)".

$\mathrm{H} 5 \mathrm{~b}$ is accepted, which means indicates that respondents' perception of security influenced them to use the QR Code which in this case is to scan the QR Code. When they feel safe, they will scan the QR Code without questioning anything. According to [11] states that the feeling of safety (perceived web security) are the main factors that influence persons to conduct transactions online, this finding is also consistent with the findings of [11].

10)H6: "Perceived Behavioral Control (PBC)" has a positive effect on "Intention to Scan (ITS)".

H6 is rejected, which means that the effect of perceived behavioral control does not affect respondents' intention to scan the QR Code. In other words, persons with or without control will still scan the QR Code. The results of this study contrast with [13] who found that attitudes and perceived behavioral control has a strong positive influence on the behavioral intention.
11)H7: "Self Efficacy (SE)" has a positive effect on "Perceived Behavioral Control (PBC)".

$\mathrm{H} 7$ is accepted, which means that the respondents find it easy to scan the QR Code, without any special help or capability. These results are consistent with [13] that selfefficacy influences perceived behavioral control. But in this study self-efficacy will affect the intention of respondents to scan the QR Code only if the hypothesis H6 is accepted because self-efficacy has an indirect impact on the intention to scan.

12)H8: "Perceived Risk (PCR)" has a positive effect on "Intention to Scan (ITS)".

$\mathrm{H} 8$ is accepted, which means that the perception of risk by respondents would affect their intention to scan the QR Code. When they know and understand the risks that may arise, it can be taken into consideration before they scan the QR Code. This is consistent with the findings [14] that the perceived risk is an important factor that affects a person's intention.

\section{CONCLUSION AND RECOMMENDATION}

From the discussion, it can be concluded that respondents' intention to scan QR Code technology is directly affected by a respondents' attitude, perceived security and perceived risk. While Perceived Usefulness (PU) and Perceived Behavioral Control (PBC) do not affect respondent's intention to scan the QR Code. In addition, they will not immediately scan the QR Code even though they know that scan the QR Code will not be difficult before they think that the decision to scan is completely positive and profitable. Based on the overall model fit test results shows that the model used in this study is suitable and appropriate to examine the factors that affect person's intention to scan the QR Code. For future study, this research model can be used with different object, demographics and different location and also could be added new relevant constructs, so that it can be used as a comparison with the results of this study.

This study is the first step to appeal and increase user safety awareness in order not to scan QR Code without any proper tool to be able to automatically detect attacks caused by $\mathrm{QR}$ Code scan.

APPENDIX

\begin{tabular}{|l|l|}
\hline \multicolumn{2}{|l|}{\begin{tabular}{l|} 
Perceived Usefulness (PU) \\
According to [11]
\end{tabular}} \\
\hline a & $\begin{array}{l}\text { Using the QR Code would enable me to accomplish my tasks more } \\
\text { quickly }\end{array}$ \\
\hline b & Using the QR Code would me it easier for me to carry out my tasks \\
\hline c & I would find that the QR Code useful \\
\hline d & Overall, I would find using the QR Code to be advantageous \\
\hline \begin{tabular}{|l|l|}
\hline Perceived Ease of Use (PEOU) \\
According to [11]
\end{tabular} \\
\hline a & Using the QR Code service is easy for me \\
\hline b & $\begin{array}{l}\text { I find my interaction with the QR Code services clear and } \\
\text { understandable }\end{array}$ \\
\hline
\end{tabular}




\begin{tabular}{|l|l|}
\hline c & It is easy for me to become skillful in the use of the QR Code \\
\hline d & Overall, I find the use of the QR Code services easy \\
\hline
\end{tabular}

\begin{tabular}{|c|c|}
\hline \multicolumn{2}{|c|}{$\begin{array}{l}\text { Trust (T) } \\
\text { According to [12] }\end{array}$} \\
\hline $\mathbf{a}$ & I trust the QR Code that I scanned \\
\hline b & I trust the information in the QR Code that I scanned \\
\hline c & I trust the source who has made a QR Code that I scanned \\
\hline d & I believe that if I scan QR Code, I can meet needs or things that I want \\
\hline
\end{tabular}

\begin{tabular}{|l|l|}
\hline \multicolumn{2}{|l|}{$\begin{array}{l}\text { Perceived Security (PS) } \\
\text { According to [11] }\end{array}$} \\
\hline a & I would feel secure when I scan QR Code \\
\hline b & QR Code is secure to be scanned \\
\hline c & I would feel totally secure to scan QR Code \\
\hline d & Overall, QR Code is secure to be scanned \\
\hline
\end{tabular}

\begin{tabular}{|l|l|}
\hline \multicolumn{2}{|l|}{ Attitude (ATT) } \\
According to [11]\& [13] \\
\hline a & Using the QR Code is a good idea \\
\hline b & I would feel that using the QR Code is pleasant \\
\hline c & In my opinion, it would be desirable to use the QR Code \\
\hline d & $\begin{array}{l}\text { The advantage using the QR Code outweighs the advantages of not } \\
\text { using it }\end{array}$ \\
\hline e & In my opinion, using the QR Code is a wise idea \\
\hline
\end{tabular}

\begin{tabular}{|l|l|}
\hline \multicolumn{2}{|l|}{$\begin{array}{l}\text { Intention to Scan (ITS) } \\
\text { According to [11] }\end{array}$} \\
\hline a & I would use the QR Code for my activities or to get things that I want \\
\hline b & $\begin{array}{l}\text { Using the QR Code for handling my activities or to get things that I } \\
\text { want is something I would do }\end{array}$ \\
\hline c & $\begin{array}{l}\text { I would see myself using the QR Code for handling my activities or to } \\
\text { get things that I want is something I would do }\end{array}$ \\
\hline $\begin{array}{l}\text { Perceived behavioral control (PBC) } \\
\text { According to [13] }\end{array}$ \\
\hline a & I have the knowledge and ability to use the QR Code \\
\hline b & Using the QR Code technology is entirely within my control \\
\hline
\end{tabular}

\begin{tabular}{|l|l|}
\hline \multicolumn{2}{|l|}{$\begin{array}{l}\text { Self-efficacy (SE) } \\
\text { According to [13] }\end{array}$} \\
\hline a & I know enough to use the QR Code technology \\
\hline b & I could easily use the QR Code technology on my own \\
\hline c & I would feel comfortable using the QR Code \\
\hline
\end{tabular}

\section{Performance Risk (PFR)}

According to [14]

QR Code might not perform well and create problems for my activity a $\quad$ or things that I want

b The probability that something's wrong with the performance of QR

b Code is high

c Considering the expected level of service performance of QR Code, c for me to use QR Code it would be risky

\begin{tabular}{|l|l|}
\hline \multicolumn{2}{|l|}{ Time Risk (TR) } \\
According to [14] \\
\hline a & $\begin{array}{l}\text { I think that if I use the QR Code the I will lose time due to having to } \\
\text { switch to a different way to help my activity or things I want }\end{array}$ \\
\hline b & $\begin{array}{l}\text { Using QR Code would lead to a loss of convenience for me becase I } \\
\text { would have to waste a lot of time for adapting }\end{array}$ \\
\hline
\end{tabular}

\section{Social Risk (SR)}

According to [14]

\begin{tabular}{|l|l} 
If I use the QR Code, it would negatively affect the way others think \\
\hline
\end{tabular} a of me

b Using the QR Code would lead to a social loss for me because my

b friends and relatives would think less highly of me

\begin{tabular}{|c|c|}
\hline \multicolumn{2}{|c|}{$\begin{array}{l}\text { Overall Risk (ORI) } \\
\text { According to [14] }\end{array}$} \\
\hline $\mathbf{a}$ & $\begin{array}{l}\text { On the whole, considering all sorts of factors combined, it would be } \\
\text { risky if I use QR Code }\end{array}$ \\
\hline b & $\begin{array}{l}\text { Using the QR Code to help my activity or things that I want would be } \\
\text { risky }\end{array}$ \\
\hline c & QR Code is dangerous to use \\
\hline d & $\begin{array}{l}\text { I think that using of QR Code would add great uncertainty to my } \\
\text { activity or things that I want would }\end{array}$ \\
\hline
\end{tabular}

\section{REFERENCES}

[1] Scanlife. "Mobile Trend Report Q3 2015,”. 2016

[2] Google Trend, "QR Code,". 2016

[3] Kurniawan, Haris."Ditjen Hubla Kemenhub berlakunya QR Code," Merdeka.com. 2016

[4] Direktorat Jenderal Pajak."Selamat Datang Era e-Faktur Pajak!,”. 2015

[5] MUI.“MUI Bangun Aplikasi Berbasis QR Code Scanner,”. 2015

[6] J. Seeburger. No cure for curiosity: linking physical and digital urban layers. In Proceedings of the 7th Nordic Conference on HumanComputer Interaction: Making Sense Through Design, pages $247\{256$. ACM, 2012.

[7] Iskandar. "Aneh, QR Code di Botol Ini Tuntun Pengguna ke Situs Porno," Tekno.Liputan6.com. 2015

[8] Taufiqurrakhman, Ahmad."Penipuan Pun Kini Memakai QR Code, 'Techno.okezone.com. 2011

[9] Kieseberg, Peter., Leithner, Manuel., Mulazzani, Martin., Munroe, Lindsay., Schrittwieser, Sebastian., Sinha, Mayank., \& Weippl, Edgar."Qr Code Security,"In Proceedings of the 8th International Conference on Advances in Mobile Computing and Multimedia, pages 430-435. 2010

[10] T. Vidas, E. Owusu, S. Wang, C. Zeng, L. F. Cranor, and N. Christin. QRishing:The Susceptibility of Smartphone Users to QR Code Phishing Attacks. In Proceedings of the 2013 Workshop on Usable Security (USEC'13), 2013.

[11] Cheng, T.C Edwin., Lam, David Y.C., \& Yeung, Andy C.L.“Adoption of Internet Banking: An Empirical Study in Hongkong," Department of Logistics, The Hong Kong Polytechnic University. 2006 
[12] Shin, Dong-Hee."The effect of trust, security and privacy in social networking: A security-based approach to understand the pattern of adoption,"Department of Interaction Science, Sungkyunkwan Univeristy. 2010.

[13] Ajjan, Haya., \& Hartshorne, Richard. "Investigating Faculty Decisions to Adopt Web 2.0 Technologies: Theory and Empirical Tests,"University of North Carolina at Charlotte, United States. 2008

[14] Martins, Carolina., Oliveira, Tiago., \&Popovic, Ales."Understanding the Internet Banking Adoption: A Unified Theory of Acceptance and Use of Technology and Perceived Risk Application,"Faculty of Economics, University of Ljubljana. 2013

[15] Vidas, Timothy., Owusu, Emmanuel., Wang, Shuai., Zeng, Cheng.,\& Cranor, Lorrie."Qrishing: The Susceptibility of Smartphone Users to QR Code Phishing Attacks," Carnegie Mellon University Pittsburgh, PA, USA. 2012

[16] Sarwono, Jonathan."PengertianDasar Structural Equation Modeling (SEM),"JurnallmiahManajemenBisnis, Vol. 10, No. 3, September 2010: 173182. 2010

[17] Sofyan., \& Kurniawan, Heri.Structural Equation Modelling Belajar Lebih Mudah Teknik Analisis Data Kuisioner dengan Lisrel-PLS, Jakarta: Salemba Infotek. 2009

[18] A. Gliem, Joseph., \& R. Gliem, Rosemary."Calculating, Interpreting, and Reporting Cronbach's Alpha Reliability Coefficient for Likert-Type
Scales,"Mildwest Research to Practice Conference in Adult, Continuing, and Community Education. 2003

[19] Kartika, Jenetha dan Muchsinati, Evi Silvana.“Analisis Faktor-Faktor yang Mempegaruhi Organizational Citizenship Behavior pada Karyawan BPR di Batam. Universitas Internasional Batam,” Jurnal Manajemen, Vol.14, No.2. 2015

[20] Field, Andy. Discovering Statistics Using SPSS, Third Edition, Los Angeles: Sage. 2009

[21] Benko, Michal."Testing the Equality of Means and Variances across Populations and Implementation in XploRe,"Humboldt Universit"atzu Berlin. 2001

[22] Wiyono, Gendro.Merancang Penelitian Bisnis dengan Alat Analisis SPSS 17.0 \&SmartPLS 2.0, Yogyakarta: STIM YKPN. 2011

[23] Chandio, Fida Hussain. "Studying Acceptance of Online Banking Information System: a Structural Equation Modeling," Brunel University West London. 2011

[24] Hooper, Daire., Coughlan, Joseph.,\& Mullen, Michael.“Structural Equation Modelling: Guidelines for Determining Model Fit. Dublin Institute of Technology," The Electronic Journal of Business Research Methods Volume 6 Issue 1 2008, pp. 53 - 60. 2008

[25] Law, Kritika."Impact of Perceived Security on Consumer Trust in Online Banking,"AUT University Auckland, New Zealand. 2007

[26] Davis, Fred D., P. Bagozzi, Richard., R. Warshaw, Paul."User Acceptance of Computer Technology: a Comparison of Two Theorical Models,"The Institute of Management Science, Management Science, Vol. 35. No. 8. 1989 